\title{
THE RELATIVE EFFICIENCY OF THE DIFFERENT MER- CURIAL PREPARATIONS IN THE TREATMENT OF CONGENITAL SYPHILIS IN INFANTS AND CHILDREN
}

\author{
AS DETERMINED BY A QUANTITATIVE ANALYSIS OF THE MERCURY \\ ELIMINATED IN THE URINE*
}

WALTER REEVE RAMSEY, M.D. Associate Professor of Pediatrics, University of Minnesota Medical School ST. PAUL

AND

MILDRED R. ZIEGLER, M.S.

Instructor in Pediatrics, University of Minnesota Medical School MINNEAPOLIS

In spite of the different forms of arsenic used under various trade names, mercury, in some form, still holds the foremost place in the treatment of syphilis. Even when the arsenic preparations are used, mercury is usually continued for long periods in order to effect a cure.

Many of the salts of mercury, including metallic mercury itself, are administered in various ways: by mouth, by insufflation, subcutaneously and by inunction.

\section{ABSORPTION AND ELIMINATION OF MERCURY}

Owing to the difficulty in detecting mercury in the body fluids, little light has been thrown on the question as to what extent the different forms of mercury were absorbed and how eliminated. Meyer and Gottleib" state, "the excretion of mercury in the urine offers a means of estimating the amounts of mercury circulating in the body and the duration of its action. After absorption it circulates as a compound of mercury albuminate and sodium chlorid. It is chiefly excreted in the feces and only small amounts in the urine, and that the mercury present in the circulation probably maintains a definite ratio to the amount excreted in the urine." "The determination of the curves of elimination of mercury is of importance for the estimation of the value of different methods of administration." ${ }_{2}$ Jones $^{3}$ states, "mer-

\footnotetext{
* Submitted for publication July 15, 1918.

* Read at the meeting of the American Pediatric Society, Lenox, Mass., May, 1918.

1. Meyer and Gottleib: Pharmacology, Clinical and Experimental. Philadelphia, J. B. Lippincott Company.

2. Burgi : Arch. f. Dermatol. u. Syph., 79, 1906.

3. Jones: Brit. Med. Jour., 1888, p. 660.
} 
cury is chiefly eliminated by the urine and when it causes purgation, more is eliminated by the bowel."

Whether mercury by inunction is absorbed by the skin, has long been a cource of controversy. Up to the present year, many of the foremost authorities have claimed that no mercury was absorbed by the skin, but that the mercury was volatilized by means of the body heat and absorbed through the respiratory tract.

Wile and Elliot, ${ }^{4}$ by employing a modification of the Reinsch method, were able to detect as small an amount of mercury as 0.025 $\mathrm{mg}$. in 300 c.c. of urine. By using this method they were able to demonstrate that "the mode of absorption of mercury in the inunction cure is both by volatilization and by direct absorption through the skin." Schamberg, Kolmer, Raiziss and Gavron, ${ }^{5}$ in an experimental study on rabbits, were able to demonstrate that "the chief avenue of absorption of mercury when applied by inunction is the skin and that rabbits may be fatally poisoned with mercury by inunction, even when no opportunity of absorption through the lungs exists."

\section{LITERATURE ON THIS SUBJECT}

So far as we have been able to determine in reviewing the literature, no work has been done on the elimination of mercury in the treatment of syphilis in infants and children.

$\mathrm{Up}_{\mathrm{p}}$ to the present time, the form, dose and method of administration of mercury in the treatment of syphilis in infants and children have been more or less haphazard. Almost all of the modes are in vogue, the physician using the method which seems in his hands, to produce the best clinical results or, frequently, the one which may be given with the least suspicion as to what is being given.

Whatever form of mercury is administered, the object has been to produce a disappearance of the symptoms of syphilis and maintain the mercurial dosage in such quantities, for long periods of time, as to keep within the tolerance as indicated by salivation and diarrhea. That mercury, even by inunction in sufficient doses, is toxic to rabbits was shown in the experiments by Schamberg and his associates. ${ }^{5}$ In these experiments five rabbits were given from two to four inunctions of calomel ointment or mercury ointment. All of the rabbits died and showed acute hyperemia of the glomeruli and cloudy swelling of the parenchyma.

4. Wile and Elliot: Mode of Absorption of Mercury in the Inunction Treatment of Syphilis, Jour. Am. Med. Assn., 1917, 68, 1024; Jour. Cutan. Dis., 1917, 35, 594.

5. Schamberg, Kolmer, Raiziss and Gavron: Experimental Studies of the Mode of Absorption of Mercury When Applied by Inunction, Jour. Am. Med. Assn., 1918, 70, 142. 


\section{OBJECT OF THE AUTHORS' EXPERIMENTS}

Our series of experiments was undertaken to determine, if possible, the extent of absorption of mercury into the circulation as indicated by the elimination in the urine, when the ordinary methods and dosage were employed and the time during which mercury continues to be eliminated in the urine after the mercury has been discontinued. The idea was to determine the frequency and size of the dose necessary to maintain mercury circulating in the body fluids, having assumed, as stated by Meyer and Gottleib, that the excretion of mercury in the urine offers a means of estimating the amount of mercury circulating in the body and that the success of the treatment depends on a certain amount of mercury in the body fluids. The effects of the various forms of mercury on the kidneys as determined by the appearance of protein, casts, or blood in the urine, was also to be estimated when possible.

Our first series of experiments were carried out according to the Elliot ${ }^{6}$ method.

This series consisted of the following cases:

\section{REPORT OF CASES}

CASE 1.-Baby G., aged 2 weeks, was born with typical syphilitic lesions. A 1:1,000 mercuric chlorid solution was given, 10 drops, three times daily. Mercury was readily detected in the urine after the second day (not examined earlier). The mercury was discontinued and after one week the urine still contained traces. The urine, while this treatment was continued, contained appreciable amounts of protein and granular casts. The symptoms of syphilis rapidly cleared up under this treatment. Two months later, when having mercury ointment under the abdominal band, $0.5 \mathrm{gm}$. daily, appreciable amounts of mercury were found in the urine. May 17, two weeks after all treatment had been discontinued, distinct traces of mercury were found.

CASE 2.-Baby girl R., aged 5 days, had congenital syphilis. One gram of $33 \frac{1}{3}$ per cent. mercurial ointment was rubbed into the skin. On the second day mercury was readily detected in the urine and it is probable that it could have been detected earlier if examined.

CASE 3.-Baby boy L., newborn, was given $0.03 \mathrm{gm}$. of gray powder on December 5 . On December 6, 7 and 8 mercury was readily detected in the urine.

CASE 4.-Edna B., aged 25 months, had congenital syphilis. She received $0.03 \mathrm{gm}$. of gray powder December 5. December 6, mercury was readily detected in the urine, also present December 8.

CASE 5.-Baby boy P., aged 4 days, was given $0.03 \mathrm{gm}$. of gray powder for three doses on the fourth day. On the sixth and eighth days mercury appeared in the urine.

CASE 6.-Baby girl R., aged 20 months, had congenital syphilis. She received seven inunctions of $0.5 \mathrm{gm}$. of $33^{1 / 3}$ per cent. mercury ointment before the urine was examined. Urine contained appreciable amounts of mercury.

CASE 7.- Baby boy J., aged 11 months, had congenital syphilis. He received two inunctions of $0.5 \mathrm{gm}$. of $33 \frac{1}{3}$ per cent. mercury ointment. Following the second inunction mercury was readily detected in the urine.

6. Elliot, J. A.: A New and Delicate Method for the Detection of Mercury, Jour. Am. Med. Assn., 1917, 68, 1693. 
Results of a Series of Experiments to Determine the Elimination OF MERCURY IN THE URINE

\begin{tabular}{|c|c|c|c|c|c|c|c|}
\hline$\underset{\mathbf{A g} \theta}{\operatorname{Name}}$ & Dlagnosis & $\begin{array}{c}\text { Form } \\
\text { of } \\
\text { Mercury }\end{array}$ & Dose & $\begin{array}{l}\text { Date of } \\
\text { Treat- } \\
\text { ment }\end{array}$ & $\begin{array}{l}\text { Date of } \\
\text { Exami- } \\
\text { nation }\end{array}$ & $\begin{array}{l}\text { Amt. } \\
\text { of } \\
\text { Mer. } \\
\text { cury } \\
\text { in Mg. }\end{array}$ & Remarks \\
\hline$\underset{21}{\text { W. }_{21}}$. & $\begin{array}{l}\text { Cerebro- } \\
\text { spinal } \\
\text { syphilis }\end{array}$ & $\begin{array}{l}\text { Gray pow* } \\
\text { der and } \\
\text { mercurial } \\
\text { ointment }\end{array}$ & $\begin{array}{l}0.03 \mathrm{gm} . \\
1.5 \mathrm{gm} . \\
\text { every } \\
\text { day for } \\
\text { six days }\end{array}$ & $\begin{array}{l}2 / 22 \text { to } 3 / 8, \\
\text { inclusive } \\
\text { Gray pow- } \\
\text { der discon- } \\
\text { tinued, } 3 / 8 \\
\text { Treatment } \\
\text { discontin- } \\
\text { ued, } 3 / 26\end{array}$ & $\begin{array}{l}2 / 28 \\
3 / 1 \\
3 / 2 \\
3 / 3 \\
3 / 7 \\
3 / 8 \\
3 / 12 \\
3 / 26 \\
3 / 28 \\
3 / 29 \\
4 / 2 \\
4 / 8 \\
4 / 9 \\
4 / 10 \\
4 / 12\end{array}$ & $\begin{array}{l}+ \\
+ \\
+ \\
+ \\
0.44 \\
0.97 \\
+ \\
+ \\
+ \\
+ \\
+ \\
1.5 \\
0.2 \\
+ \\
+\end{array}$ & $\begin{array}{l}\text { Appreciable amounts } \\
\text { of protein in urine } \\
\\
\text { Elimination of con- } \\
\text { siderable amounts } \\
\text { after periods during } \\
\text { whleh there were } \\
\text { only traces suggest- } \\
\text { ing stored mercury } \\
\text { in some organ }\end{array}$ \\
\hline $\begin{array}{c}\text { c. } 0 . \\
9 \\
\text { years }\end{array}$ & $\begin{array}{c}\text { Endoear- } \\
\text { ditis; } \\
\text { edema }\end{array}$ & $\begin{array}{c}\text { Mercurial } \\
\text { ointment }\end{array}$ & $\begin{array}{c}1.5 \mathrm{gm} . \\
33 \% \% \\
\text { mercury } \\
\\
1.5 \mathrm{gm} . \\
33 \% \% \\
\text { mercury } \\
1.5 \mathrm{gm} . \\
331 \% \% \\
\text { mercury } \\
1.5 \mathrm{gm} . \\
333 \% \\
\text { mercury }\end{array}$ & $\begin{array}{l}3 / 19 \\
4 / 5\end{array}$ & $\begin{array}{c}3 / 19 \\
3 / 20 \\
3 / 21 \text { to } \\
4 / 5 \\
4 / 6 \\
\\
4 / 7 \\
\\
4 / 8\end{array}$ & $\begin{array}{l}+ \\
\pm \\
+ \\
+ \\
+ \\
+\end{array}$ & $\begin{array}{l}\text { Note large amounts } \\
\text { of mercury given } \\
\text { and little elimina- } \\
\text { tion. Did the edema } \\
\text { have anything to } \\
\text { do with this lack of } \\
\text { absorption? } \\
\text { Discharged }\end{array}$ \\
\hline $\begin{array}{l}\text { E. B. } \\
11 \\
\text { years }\end{array}$ & $\begin{array}{c}\text { Oongenital } \\
\text { syphilis }\end{array}$ & $\begin{array}{c}\text { Mercury } \\
\text { salicylate } \\
\text { in oil }\end{array}$ & $\mid \begin{array}{c}\cdots \cdots \\
0.5 \text { c.e. }= \\
0.0325 \mathrm{gm} . \\
\text { mercury } \\
\text { salicylate }\end{array}$ & $4 / 25$ & $\begin{array}{c}4 / 18 \text { and } \\
21 \\
4 / 26 \\
4 / 27 \\
5 / 1 \\
5 / 2 \\
5 / 3 \\
5 / 4 \\
5 / 5 \\
5 / 6 \\
5 / 8 \\
5 / 9 \\
5 / 10 \\
5 / 12 \\
5 / 16 \\
5 / 21\end{array}$ & $\begin{array}{l}- \\
0.5 \\
+ \\
+ \\
+ \\
+ \\
1.0 \\
+ \\
0.35 \\
0.5 \\
+ \\
+ \\
+ \\
+ \\
+\end{array}$ & $\begin{array}{l}\text { Had had mercury } \\
\text { long time before }\end{array}$ \\
\hline$\underset{\substack{\text { B. } \\
\text { years }}}{\text {. }}$ & $\begin{array}{c}\text { Congenital } \\
\text { syphilis }\end{array}$ & $\begin{array}{l}\text { Mercuric } \\
\text { chlorid } \\
\begin{array}{c}\text { Mercury } \\
\text { salicylate } \\
\text { in oil }\end{array}\end{array}$ & $\begin{array}{c}1: 1000 \\
\text { solution, } \\
10 \text { drops } \\
\text { three } \\
\text { doses } \\
\text { only } \\
\\
0.5 \text { c.c. }= \\
0.0325 \text { gm. }\end{array}$ & $4 / 26$ & $\begin{array}{l}4 / 27 \\
4 / 28 \\
4 / 29 \\
4 / 30 \\
5 / 1 \\
5 / 2\end{array}$ & $\begin{array}{l}+ \\
0.4 \\
+ \\
+ \\
+ \\
0.25\end{array}$ & $\begin{array}{l}\text { Appreciable amounts } \\
\text { of protein in urine. } \\
\text { A few granular and } \\
\text { hyaline casts }\end{array}$ \\
\hline
\end{tabular}


Results of a Series of Experiments to Determine the Elimination of Mercury in the URINe-(Continued)

\begin{tabular}{|c|c|c|c|c|c|c|c|}
\hline $\begin{array}{c}\text { Name } \\
\text { and } \\
\text { Age }\end{array}$ & Diagnosis & $\begin{array}{c}\text { Form } \\
\text { of } \\
\text { Mercury }\end{array}$ & Dose & $\begin{array}{l}\text { Date of } \\
\text { Treat- } \\
\text { ment. }\end{array}$ & $\begin{array}{l}\text { Date of } \\
\text { Exami- } \\
\text { nation }\end{array}$ & $\begin{array}{c}\text { Amt. } \\
\text { of } \\
\text { Mers } \\
\text { cury } \\
\text { in Mg. }\end{array}$ & Remarks \\
\hline $\begin{array}{l}\text { D. G. } \\
\text { years }\end{array}$ & $\begin{array}{c}\text { Chorea } \\
\text { minor }\end{array}$ & Calomel & $\mid \begin{array}{c}0.016 \mathrm{gm} \\
\text { four } \\
\text { doses }\end{array}$ & $5 / 10$ & $\begin{array}{l}5 / 11 \\
5 / 12 \\
5 / 13 \\
5 / 17 \\
5 / 18 \\
5 / 19 \\
5 / 20 \\
5 / 21 \\
5 / 22 \\
5 / 23\end{array}$ & $\begin{array}{l}+ \\
+ \\
+ \\
+ \\
+ \\
+ \\
+ \\
+ \\
+ \\
+\end{array}$ & $\begin{array}{l}\text { Bowels loose. Prob- } \\
\text { ably eliminated in } \\
\text { feces }\end{array}$ \\
\hline$\underset{\text { years }}{\mathbf{L} .}$ & $\begin{array}{l}\text { Oongenital } \\
\text { syphilis; } \\
\text { periostitis }\end{array}$ & $\begin{array}{c}\text { Mercury } \\
\text { ointment } \\
50 \\
\text { Mercury } \\
\text { salicylate } \\
\text { in oll } \\
\text { hypoderm } \\
\text { leally }\end{array}$ & $\begin{array}{l}1 \mathrm{gm} . \text { on } \\
\mathrm{knee} \text { and } \\
\text { leg daily } \\
0.5 \mathrm{ccce} \text { or } \\
0.0325 \mathrm{gm} .\end{array}$ & $\begin{array}{c}\text { Daily up to } \\
4 / 10, \text { dis- } \\
\text { continued } \\
4 / 27\end{array}$ & $\begin{array}{l}4 / 11 \\
4 / 27 \\
4 / 28 \\
5 / 1 \\
5 / 2 \\
5 / 8 \\
5 / 4\end{array}$ & $\begin{array}{l}0.54 \\
\pm \\
+ \\
0.25 \\
+ \\
+ \\
+\end{array}$ & \\
\hline $\begin{array}{l}\text { c. N. } \\
\text { is. } \\
\text { years }\end{array}$ & $\begin{array}{l}\text { Congenital } \\
\text { gyphills: } \\
\text { periostitis }\end{array}$ & $\begin{array}{c}\begin{array}{c}\text { Mercurial } \\
\text { ointment }\end{array} \\
\begin{array}{c}\text { Mercury } \\
\text { salicylate } \\
\text { in oil }\end{array}\end{array}$ & $\begin{array}{c}1 \mathrm{gm} . \\
\text { dally } \\
\text { around } \\
\text { knee } \\
0.5 \text { c.c. } \\
0.0825 \mathrm{gm} .\end{array}$ & $\begin{array}{r}\text { Daily } \\
4 / 27\end{array}$ & $\begin{array}{l}4 / 18 \\
4 / 27 \\
\\
4 / 28 \\
4 / 30 \\
5 / 1 \\
5 / 5\end{array}$ & $\begin{array}{l} \pm \\
+ \\
+ \\
+\end{array}$ & $\begin{array}{l}\text { All treatment discon- } \\
\text { tinued } 4 / 13 \\
\text { Traces of protein in } \\
\text { urine. Few casts }\end{array}$ \\
\hline $\begin{array}{c}\text { O. M. } \\
3 \\
\text { years }\end{array}$ & Malnutrition & $\begin{array}{l}\text { Mercury } \\
\text { chlorid }\end{array}$ & $\begin{array}{c}0.5 \text { c.c. of } \\
1 \% \text { so- } \\
\text { lution } \\
\text { hypod. }\end{array}$ & $5 / 17$ & $\begin{array}{c}5 / 18 \\
5 / 19 \\
5 / 20 \\
5 / 21 \\
5 / 22-23\end{array}$ & $\begin{array}{l}+ \\
+ \\
+ \\
+ \\
+\end{array}$ & \\
\hline $\begin{array}{l}\text { F. } 0 . \\
5 \\
\text { years }\end{array}$ & Burn; sear & $\begin{array}{l}\text { Mereury } \\
\text { chlorid }\end{array}$ & $\begin{array}{c}0.5 \text { c.c. of } \\
1 \% \text { so- } \\
\text { lution } \\
\text { hypod. }\end{array}$ & 5/17 & $\begin{array}{c}5 / 18 \\
5 / 19 \\
5 / 20 \\
5 / 21 \\
5 / 22-23\end{array}$ & $\begin{array}{l}+ \\
+ \\
+ \\
\pm \\
+\end{array}$ & \\
\hline $\begin{array}{l}\text { J. D. } \\
\text { b } \\
\text { years }\end{array}$ & Cystitis & Calomel & $\mid \begin{array}{c}0.016 \mathrm{gm} \\
\text { for tour } \\
\text { doses }\end{array}$ & $5 / 11$ & $\begin{array}{l}5 / 12 \\
5 / 12 \\
5 / 14 \\
5 / 15 \\
5 / 16 \\
5 / 17 \\
5 / 18 \\
5 / 19 \\
5 / 22\end{array}$ & $\begin{array}{l}0.4 \\
+ \\
+ \\
+ \\
+ \\
+ \\
+ \\
+ \\
+\end{array}$ & \\
\hline $\begin{array}{c}\text { Boy } \mathrm{T} . \\
\text { I } \\
\text { year }\end{array}$ & $\begin{array}{c}\text { Congenital } \\
\text { syphilis }\end{array}$ & Oalomel & $\mid \begin{array}{c}0.016 \mathrm{gm} \\
\text { for four } \\
\text { doses }\end{array}$ & $\begin{array}{l}3 / 14 \\
3 / 16 \\
3 / 17 \\
4 / 10\end{array}$ & $3 / 15$ & $\ddot{t}$ & $\begin{array}{l}\text { This case had had } \\
\text { mercury inunction } \\
\text { for considerable } \\
\text { time, but it had } \\
\text { been discontnued } \\
\text { two weeks before } \\
\text { calomel treatment }\end{array}$ \\
\hline $\begin{array}{l}\text { G. } 8 . \\
8 \text { years }\end{array}$ & $\begin{array}{l}\text { Diabetes } \\
\text { mellitus }\end{array}$ & $\begin{array}{l}\text { Mercurial } \\
\text { ointment }\end{array}$ & $\left|\begin{array}{c}1.5 \mathrm{gm} . \\
331 \% \% \\
\text { mercury }\end{array}\right|$ & $4 / 4$ & $\begin{array}{l}4 / 5 \\
4 / 56 \\
4 / 9 \\
4 / 12\end{array}$ & $\begin{array}{l}1.3 \\
+ \\
+ \\
+\end{array}$ & \\
\hline
\end{tabular}


Results of a Series of Experiments to Determine the Elimination of MERCURY IN THE URINE-(Continued)

\begin{tabular}{|c|c|c|c|c|c|c|c|}
\hline $\begin{array}{l}\text { Name } \\
\text { and } \\
\text { Age }\end{array}$ & Diagnosis & $\begin{array}{c}\text { Form } \\
\text { of } \\
\text { Mercury }\end{array}$ & Dose & $\begin{array}{l}\text { Date of } \\
\text { Treat- } \\
\text { ment }\end{array}$ & $\begin{array}{l}\text { Date of } \\
\text { Exami- } \\
\text { nation }\end{array}$ & $\begin{array}{c}\text { Amt. } \\
\text { of } \\
\text { Mer- } \\
\text { cury } \\
\text { in Mg. }\end{array}$ & Remarks \\
\hline $\begin{array}{l}\text { J.C. } \\
6 \\
\text { years }\end{array}$ & $\begin{array}{l}\text { Syphillitic } \\
\text { periostitis }\end{array}$ & $\begin{array}{l}\text { Mercurial } \\
\text { ointment }\end{array}$ & $\begin{array}{c}1.5 \mathrm{gm} . \\
33 \% \% \\
\text { mercury }\end{array}$ & $3 j 12$ & $\begin{array}{l}3 / 13 \\
3 / 14 \\
3 / 15 \\
3 / 16 \\
3 / 18 \\
3 / 19 \\
3 / 20\end{array}$ & $\begin{array}{l}1.0 \\
0.10 \\
0.12 \\
0.10 \\
\pm \\
=\end{array}$ & $\begin{array}{l}\text { Approximately } \\
\text { Approximately } \\
\text { Approximately }\end{array}$ \\
\hline $\begin{array}{l}\text { Boy } P . \\
\text { 2 days }\end{array}$ & $\begin{array}{l}\text { Normal; } \\
\text { newborn }\end{array}$ & $\begin{array}{c}\text { Mercury } \\
\text { salicylate } \\
\text { in oil }\end{array}$ & $\left|\begin{array}{c}0.5 \mathrm{c} . \mathrm{c} . \\
0.0325 \mathrm{gm} .\end{array}\right|$ & $5 / 1$ & $\begin{array}{l}5 / 2 \\
5 / 3 \\
5 / 4 \\
5 / 5\end{array}$ & $\begin{array}{c}1.0 \\
+ \\
1.0 \\
+\end{array}$ & $\begin{array}{l}\text { No further examina. } \\
\text { tlon }\end{array}$ \\
\hline $\begin{array}{l}\text { Boy J. } \\
2 \text { days }\end{array}$ & $\begin{array}{c}\text { Congenital } \\
\text { syphilis }\end{array}$ & $\begin{array}{l}\text { Mercury } \\
\text { salicylate } \\
\text { in oll }\end{array}$ & $\begin{array}{c}0.5 \text { c.c. }- \\
0.0325 \mathrm{gm} .\end{array}$ & 5,3 & $\begin{array}{l}5 / 4 \\
5 / 6 \\
5 / 10\end{array}$ & $\begin{array}{l}0.3 \\
+ \\
+\end{array}$ & Discharged \\
\hline $\begin{array}{l}\text { Boy } M . \\
5 \\
\text { months }\end{array}$ & $\begin{array}{l}\text { Congenital } \\
\text { syphilis }\end{array}$ & $\begin{array}{c}\text { Mereury } \\
\text { ointment } \\
\text { under band } \\
\text { for past } \\
\text { month }\end{array}$ & $\begin{array}{c}0.12 \mathrm{gm} . \\
\text { mercury } \\
\text { ofnt- } \\
\text { ment }\end{array}$ & $\begin{array}{l}5 / 1 \text { dis- } \\
\text { continued }\end{array}$ & $\begin{array}{l}5 / 2 \\
5 / 9 \\
5 / 16\end{array}$ & $\begin{array}{c}+ \\
0.75 \\
+\end{array}$ & $\begin{array}{c}\text { Treatment discon- } \\
\text { tinued }\end{array}$ \\
\hline
\end{tabular}

Several other new-born infants were given mercury by smearing $1 \mathrm{gm}$. of $33 \frac{1}{3}$ per cent. mercury ointment on a piece of linen and placing it in contact with the skin under the abdominal band (sealed with wax paper). Owing to the small amounts of urine collected, the results in some cases were unsatisfactory, but in many, positive traces of mercury could be demonstrated. All new-born infants left the hospital on the tenth or twelfth day.

\section{FURTHER EXPERIMENTS}

The next series of analyses were made by a modification of Heinzelmann's method. ${ }^{7}$ It was necessary on account of the difficulty of securing chemically pure zinc, to substitute aluminum for zinc and dissolve in potassium hydroxid instead of hydrochloric acid. The method is as follows:

To the twenty-four-hour specimen of urine, usually not more than 500 c.c. are used, add $1 \mathrm{gm}$. of potassium chlorate and 5 c.c. of concentrated hydrochloric acid for every 100 c.c. of urine. Heat over the free flame until the color changes from dark red to light yellow. Cool to $70 \mathrm{C}$.; add $1 \mathrm{gm}$. of very fine granulated aluminum and allow to stand over night. Decant and wash twice with about 25 c.c. of water. Dissolve in 5 c.c. of potassium hydroxid, 40 per cent.; when solution is complete add 25 c.c. of concentrated hydrochloric acid. If solution is not complete after some time heat gently, cool, pour into a Hehner cylinder and dilute to 90 c.c. with water; add 10 c.c. of saturated hydrogen sulphid water, mixing with a glass rod, which is bent into a spiral at one end. At the same time prepare a standard, using

7. Heinzelmann: Chem. Ztg., 1911, 35, 724. 
equal amounts of aluminum, potassium hydroxid, and hydrochloric acid adding with a pipet 5 or 10 c.c. of mercuric chlorid solution containing 1 or $2 \mathrm{mg}$. of mercury. Compare colorimetrically. If the day's specimen of urine is less than 100 c.c., it is diluted to 100 c.c. and carried out as above; if the amount is more than 100 c.c. and less than 500 c.c., it is used without dilution.

\section{SUMMARY AND CONCLUSIONS}

From the small series of experiments described in the foregoing charts we have drawn the following conclusions:

In infants and children, mercury, when given by the mouth, by inunction or intramuscularly, is excreted at least partly by the urine.

In new-born infants and older children mercurial ointment when placed in contact with the skin, without any friction being used (protected and sealed by wax paper from being volatilized and inhaled), is taken up by the skin and excreted in the urine and continues to be excreted in the urine for a variable time after all treatment has been discontinued.

By inunction (with rubbing) mercury is readily taken up by the skin and eliminated in the urine and continues to be eliminated for a considerable time.

When one inunction is given, the maximum daily amount of mercury is usually eliminated during the following twenty-four hours, smaller amounts being eliminated for a variable time.

Where continuous inunctions are given there is an accumulation in the system and considerable amounts are eliminated at intervals with only traces between.

It is therefore probable that it is unnecessary to have mercury in contact with the skin, either with or without rubbing as often or as long as has been generally thought necessary. This, however, must be determined by further clinical investigation.

Mercury salicylate suspended in oil and given subcutaneously continues to be eliminated in the urine in appreciable amounts for eight days, or longer, the daily amounts eliminated varying widely. It is therefore probable that a repetition of the treatment, not oftener than at intervals of eight days would be sufficient.

Mercuric chlorid by intramuscular method, a favorite method in congenital syphilis, continues to be eliminated for eight days or longer.

In all cases in which mercuric chlorid was used either by mouth or the intramuscular method protein was found in the urine.

Calomel, $0.016 \mathrm{gm}$. every two hours for four doses, and gray powder, $0.03 \mathrm{gm}$. every three hours for 3 doses, continued to be eliminated in appreciable amounts in the urine for as long as nine days; the maximum daily elimination usually occurred during the twentyfour hours following administration. It is therefore probable that 
the daily use of any of the mercurial salts in the amounts usually prescribed, is unnecessary and presumably harmful.

We shall continue our investigations and believe it is not too much to expect that in the near future, with the methods now at our disposal of estimating quantitatively the amount of mercury in the body fluids, some degree of accuracy will be attained in the treatment of syphilis by the different mercurial preparations.

We are grateful to Dr. J. P. Sedgwick, who suggested this problem, and for his constant interest in the work. 